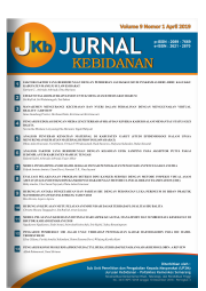

Volume 11 Nomor 2 (2021) 181-184

JURNAL KEBIDANAN

p-ISSN: 2089-7669 ; e-ISSN: 2621-2870

http://dx.doi.org/10.31983/jkb.v11i2.7797

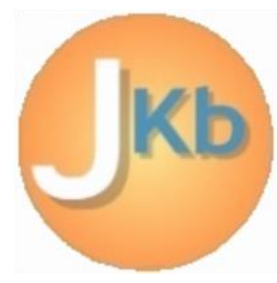

\title{
Comparison of Defection Frequency in Infant Age 0 to 4 Month between Breast Milk And Formula Milk In The Work Area Of The Toddopuli Public Health Center
}

\author{
St Hadijah H Anwar ${ }^{1}$, Rosdianah ${ }^{2}$, Abd Rahman ${ }^{2}$ \\ ${ }^{1}$ Department of Midwifery, Hasanuddin University, Indonesia \\ ${ }^{2}$ Department of Midwifery, Megarezky University, Indonesia \\ Jl. Perintis Kemerdekaan M 10 Makassar, Indonesia \\ Corresponding author: St Hadijah H Anwar \\ Email: hadijahijha15@gmail.com
}

Received: October $17^{\text {th }}, 2021$; Revised: October $26^{\text {th }}, 2021$; Accepted: October $31^{\text {th }}, 2021$

\begin{abstract}
Breast Milk is an emulsion of fat in a solution of protein, lactose, and inorganic salts secreted by the mother's mammary gland. Formula milk is cow's milk whose nutritional composition is changed in such a way that it can be given to babies without giving side effects, cow's milk itself is a milk of choice for babies who have no family history of allergies. Defecation is the act of a living for or the process of a creature removing solid or half-solid feces or stool originating from the digestive system of living things. This study aims to determine the comparison of the frequency of defecation in infants aged 0-4 months between breast milk and formula milk in the work area Makassar toddopuli health center in 2019. This study uses the Cross-Sectional Study approach which is the type of research in the form of Observation of independent and dependent variables conducted at the same time. Purposive sampling technique. The respondents of this study were 30 people. The observation was carried out for 4 months by recording the expenditure of the baby's chapters every day. Because the data is not normally distributed, the Tann Pitney statistical test was used and a $p$-value of $0,000(p<0.05)$ was obtained. So it can be concluded that the results of this study are that there is a comparison of the frequency of defecation in infants aged 0-4 months between breast milk and formula milk in Makassar toddopuli health center in 2019.
\end{abstract}

Keywords: newborns; breastmilk; formula milk; defecation frequency

\section{Pendahuluan}

ASI merupakan minuman yang dianjurkan untuk semua neonatus, termasuk bayi prematur. ASI memiliki manfaat nutrisi, imunologis dan fisiologis dibandingkan dengan susu formula atau susu jenis lainnya. ASI Ekslusif adalah bayi hanya diberi ASI saja tanpa tambahan cairan lain, seperti susu formula, jeruk, madu, air teh, air putih dan tanpa makanan padat, seperti pepaya, pisang, bubuk susu, biskuit,bubur nasi dan tim [9].

Menurut data World Health Organization (WHO) yang dipublikasikan "The Lancet" mengungkapkan bahwa peningkatan pemberian ASI ke tingkat yang hampir universal dapat menghemat dari 800.000 jiwa setiap tahunnya, sebagian menjadi anak di bawah 6 tahun. Selain itu, hampir setengah dari semua penyakit diare dan sepertiga dari semua infeksi pernafasan pada anakanak di negara- negara berpenghasilan rendah dan menengah pendapatan bisa dicegah dengan peningkatan angka menyusui. Anak-anak yang menyusui tampil lebih baik dalam tes kecerdasan. Ibu yang menyusui juga mengurangi resiko menggembangkan kanker payudara dan ovarium [27].

Dalam rangka menurunkan angka kesakitan dan kematian anak, United Nations International Children's Emergency Fund (UNICEF) dan World Health Organization (WHO) merekomendasikan sebaiknya anak hanya disusui Air Susu Ibu (ASI) selama paling sedikit 6 bulan. Beberapa penelitian 
epidemologis menyatakan bahwa ASI melindungi

bayi dan anak dari infeksi misalnya diare dan infeksi 
saluran pernafasan akut bagian bawah [15].

Mengacu pada target program pada tahun 2014 sebesar 80\%, maka secara nasional cakupan pemberian ASI ekslusif sebesar 52,3\% belum mencapai target. Menurut provinsi, hanya terdapat satu provinsi yang berhasil mencapai targetnya yaitu Nusa Tenggara Barat sebesar 84,7\%. Provinsi Jawa Barat, Papua Barat, dan Sumatra Utara merupakan tiga provinsi dengan pencapaian terendah. Sedangkan pada tahun 2015 sebesar 39\%, maka secara nasional cakupan pemberian ASI ekslusif pada bayi usia kurang dari enam bulan sebesar 55,7\% telah mencapai target. Menurut provinsi, kisaran cakupan ASI ekslusif pada bayi umur 0-6 bulan antara 26,3\% (Sulawesi Utara) sampai 86,9\% (Nusa Tenggara Barat). Dari 33 provinsi yang melapor, sebanyak 29 di antaranya (88\%) berhasil mencapai target renstra 2015 [8].

Sulawesi Selatan dapat digambarkan dengan indikator program yang dilaksanakan dalam upaya menurunkan angka kematian bayi dan balita. Di Sulawesi Selatan jumlah bayi 0-6 bulan mendapat ASI eksklusif yang diberi ASI saja tanpa makanan lain atau cairan lain berdasarkan recall 24 jam, dari pelaporan Kabupaten/Kota yaitu $71,5 \%$ dan belum mencapai angka yang dtargetkan (80\%), namun bila dibandingkan dengan cakupan tahun sebelumnya presentase cakupan untuk indikator ini mengalami peningkatan dan penurunan yaitu $67,2 \%$ di tahun 2012, 65,1 di tahun 2013, 68,45 di tahun 2014 [4].

Data angka kelahiran bayi pada Puskesmas Toddopuli menunjukkan pada tahun 2015 terdapat 305 kelahiran, pada tahun 2016 terdapat 311 kelahiran, pada tahun 2017 terdapat 313 kelahiran dan pada tahun 2018 terdapat 315 kelahiran.

Data pada Puskesmas Toddopuli Makassar menunjukkan bahwa angka ASI Eksklusif menunjukkan peningkatan dan penurunan, pada tahun 2015 terdapat 156 bayi, 2016 terdapat 163 bayi, 2017 terdapat 153 bayi dan pada tahun 2018 terdapat 148 bayi.

Dari lata belakang diatas, maka penulis tertarik untuk meneliti tentang perbandingan frekuensi defekasi bayi usia 0 sampai 4 bulan dengan asi dan susu formula untuk menilai apakah ada perbedaan frekuensi defekasi pada bayi dengan asi dan susu formula.

\section{Metode Penelitian}

Penelitian ini meggunakan pendekatan Cross Sectional Study yaitu jenis penelitian yang menekankan pengukuran Observasi Variabel independen dan dependen dilakukan dalam waktu yang bersamaan. Rancangan ini berupaya mengungkapkan hubungan (koleratif) antara variable [12]. Dilakukan pada tanggal 15 Maret - 16 Juli 2019 di Wilayah Kerja Puskesmas Toddopuli Makassar

Sampel dalam penelitian ini adalah sebagian ibu yang memiliki bayi berusia 0 sampai 4 bulan yang mengkonsumsi asi dan yang mengkonsumsi susu formula di Wilayah Kerja Puskesmas Toddopuli Makassar pada tanggal 15 Maret - 16 Juli 2019 yang berjumlah 30 bayi.

Instrumen penelitian merupakan alat yang digunakan dalam rangka menghasilkan data yang diperlukan dalam penelitian. Instrumen yang dapat digunakan antara lain, pedoman wawancara, pedoman observasi dan kusioner [12].

Dalam penelitian ini, uji yang digunakan adalah uji independent $t$ test tetapi sebelum digunakan uji independent $t$ test perlu dilakukan uji normalitas, namun karena hasil analisis yang di dapatkan ternyata tidak normal maka digunakan Uji Mann Withney dimana Uji ini merupakan uji yang digunakan untuk menguji dua sampel independen ( Two Independent Sample Tests ) dengan bentuk data Ordinal. Untuk membandingkan data dua kelompok bebas. Karena penelitian ini untuk mengetahui perbandingan frekuensi defekasi pada bayi usia 0 sampai 4 bulan antara asi dan susu formula

\section{Hasil dan Pembahasan}

Tabel 1

Distribusi Frekuensi Pemberian Makanan Pada Bayi Usia 0-4 Bulan di Wilayah Kerja Puskesmas Toddopuli Makassar

\begin{tabular}{ccc}
\hline Pemberian Makanan Pada Bayi & Frekuensi (n) & Persentase (\%) \\
\hline ASI & 15 & 50 \\
Susu Formula & 15 & 50 \\
\hline Total & 30 & 100,0 \\
\hline
\end{tabular}

Sumber : Data Primer 2019

Copyright @2021, JURNAL KEBIDANAN, http://ejournal.poltekkes-smg.ac.id/ojs/index.php/jurkeb/index 
Tabel 2

Distribusi Frekuensi Defekasi Pada Bayi Usia 0-4 Bulan di Wilayah Kerja Puskesmas Toddopuli Makassar

\begin{tabular}{cccc}
\hline Makekuensi Defekasi & Jenis Susu & Frekuensi (n) & Persentase (\%) \\
\hline \multirow{2}{*}{ Normal } & ASI & 11 & 36,7 \\
& Susu Formula & 10 & 33,3 \\
\multirow{2}{*}{ Tidak Normal } & ASI & 6 & 20 \\
& Susu Fomula & 3 & 10 \\
\hline & TOTAL & & 10300 \\
\hline
\end{tabular}

Sumber : Data Primer 2019

Tabel 3

Uji Normalitas Perbandingan Frekuensi Defekasi Pada Bayi Usia 0-4 Bulan Antara ASI Dan Susu Formula di Wilayah Kerja Puskesmas Toddopuli Makassar Tahun 2019

\begin{tabular}{c|c|c}
\hline & Nilai $\rho$ & Nilai $\alpha$ \\
\hline Usia Bayi & 0.254 & 0.05 \\
\hline Jumlah BAB & 0.000 & 0.05 \\
\hline
\end{tabular}

Sumber : spss versi 16

Tabel 4

Perbandingan Frekuensi Defekasi Pada Bayi Usia 0-4 Bulan Antara ASI Dan Susu Formula di Wilayah Kerja Puskesmas Toddopuli Makassar Tahun 2019

\begin{tabular}{ccccc}
\hline Frekuensi BAB & Mean & N & Nilai $\rho$ & Nilai $\alpha$ \\
\hline Normal & 19.62 & 21 & \multirow{2}{*}{0,000} & \multirow{2}{*}{0,05} \\
Tidak Normal & 5.89 & 9 & & \\
\hline
\end{tabular}

Sumber : Spss Versi 16

Berdasarkan penelitian yang dilakukan di Puskesmas Toddopuli Makassar pada tanggal April - Juli 2019. Populasi dalam penelitian ini adalah semua ibu yang mempunyai bayi berusia 0 sampai 4 bulan yang mengkonsumsi asi dan yang mengkonsumsi susu formula di wilayah kerja Puskesmas Toddopuli Makassar pada bulan April Juli 2019. Berdasarkan data dari Puskesmas Toddopuli Makassar diperoleh 30 sampel untuk dilakukan analisis data.

Pada tabel 4 terlihat nilai usia bayi $\rho=0.254$ $>\alpha=0,05$. Dan nilai numlah bab bayi $\rho=0.000>$ $\alpha=0,05$ maka dari itu data dikatakan teruji tidak normal. Oleh karena itu analisis hasil penelitian dilanjutkan dengan menggunakan Uji Mann Whitney.

Hasil analisis dengan menggunakan Mann whitney dapat dilihat dalam tabel berikut : Pada tabel 4.6 terlihat rata-rata jumlah $\mathrm{BAB}$ bayi yang normal adalah 19,62 dengan jumlah responden 21 . Sedangkan rata-rata jumlah $\mathrm{BAB}$ bayi yang tidak noemal adalah 5,89 dengan jumlah responden 9.

Berdasarkan hasil uji statistik Mann Whitneyi nilai $\rho=0,000<\alpha=0,05$. Dengan demikian Ho ditolak dan Ha diterima yaitu ada Perbandingan Frekuensi Defekasi Pada Bayi Usia
0-4 Bulan Antara Asi Eksklusif Dan Susu Formula di Wilayah Kerja Puskesmas Toddopuli Makassar Tahun 2019.

\section{Simpulan}

Ada perbandingan frekuensi bab pada bayi usia 0 sampai 4 bulan dengan asi, dimana perbedaan frekuensi bab yang signifikan terlihat pada bayi usia 0 sampai 2 bulan dan bayi dengan usia 3 sampai 4 bulan. Dimana bayi usia 0 sampai 2 bulan jumlah babnya lebih tinggi per harinya dari pada payi usia 3 samapai 4 bulan. Bayi usia 0 sampai 2 bulan dalam sehari memiliki jumlah bab hingga 8 kali per hari, sedangkan bayi usia 3 sampai 4 bulan dalam sehari hanya memiliki jumlah bab sebanyak 2 sampai 3 kali per hari. Ada perbandingan frekuensi bab pada bayi usia 0 sampai 4 bulan dengan susu formula, dimana perbedaan frekuensi bab yang signifikan terlihat pada bayi usia 0 sampai 2 bulan dan bayi dengan usia 3 sampai 4 bulan. Dimana bayi usia 0 sampai 2 bulan jumlah babnya lebih tinggi per harinya dari pada payi usia 3 samapai 4 bulan. Bayi usia 0 sampai 2 bulan dalam sehari memiliki jumlah bab hingga 6 kali per hari, sedangkan bayi usia 3 sampai 4 bulan dalam sehari hanya memiliki jumlah bab sebanyak 1-2 kali per hari. Dari 
penelitian yang dilakukan dapat di simpulkan bahwa Ha (Hipotesis alternatif) di terima dengan demikian Ada Perbandingan Frekuensi Defekasi Pada Bayi Usia 0 sampai 4 Bulan Antara ASI Dan Susu Formula Di Wilayah Kerja Puskermas Toddopuli Makassar tahun 2019 dimana $\mathrm{p}$ value $=$ $0,000(\mathrm{p}<0,05)$.

\section{Daftar Pustaka}

[1] Ahmad, E. H., Hakim, A., Prawirodihardjo, L., Kesehatan, B., Dan, R., Fakultas, K., \& Masyrakat, K. (2012). Faktor Determinan Status Kesehatan Bayi Neonatal Di Rskdia Siti Fatimah Makassar. KesMas, 6, 144-211.

[2] Astutik, R. Y. (2014). Payudara dan Laktasi (Edisi 2). Salemba Medika.

[3] Dewi, V. N. L. (2013). Asuhan Neonatus Bayi dan Anak Balita. Salemba Medika.

[4] Dinas Kesehatan Provinsi Sulawesi Selatan. (2015). Profil Kesehatan Sulawesi Selatan. Makassar Tahun 2015.

[5] Heryani, R. (2012). Asuhan Kebidanan Ibu Nifas Dan Menyusui. CV. Trans Info Media.

[6] Hidayat, A. A. (2008). Pengantar Ilmu Keperawatan Anak (Edisi 2). Salemba Medika.

[7] Hidayat, A. A. (2014). Metode Penelitian Kebidanan Teknik Analisis (Nurchasanah, Ed.; Edisi 1). Salemba Medika.

[8] Kementerian Kesehatan RI. (2016). PROFIL KESEHATAN INDONESIA TAHUN 2016. http://www.kemkes.go.id

[9] Khamzah, S. N. (2012). Segudang Kejaiban ASI Yang Harus Anda Ketahui. FlashBook.

[10] Maritalia, D. (2014). Asuhan Kebidanan Nifas dan Menyusui. Pustaka Pelajar.

[11] Maryunani, A. (2012). Inisiasi Menyusui Dini, ASI Eksklusif dan Manajemen Laktasi. CV. Trans Info Media.

[12] Notoatmodjo, S. (2014). Metodologi Penelitian Kesehatan. PT Rineka Cipta.

[13] Nugroho, T., Nurrezki, Warnaliza, D., \& Wilis. (2014). Buku Ajar Asuhan Kebidanan 3 Nifas. Nuha Medika.

[14] Proverawati, A., \& Rahmawati, E. (2010). Kapita Selekta ASI \& Menyusui. Nuha Medika.

[15] Pusat Data Dan Informasi Kementrian Kesehatan RI. (2014). Situasi dan Analisis ASI Eksklusif.

[16] Rianti. (2014). Mitos - Mitos dan Fakta Fakta Seputar ASI. Flash Book.
[17] Rochsitasari, N., Santosa, B., Puruhita, N., Ilmu Kesehatan anak Fakultas Kedokteran Universitas Diponegoro, B., Kariadi, R., Ilmu Gizi Klinik Fakultas Kedokteran Universitas Diponegoro, B., \& drKariadi, R. (2011). Perbedaan Frekuensi Defekasi dan Konsistensi Tinja Bayi Sehat Usia 0-4 Bulan yang Mendapat Asi Eksklusif, Non Eksklusif, dan Susu Formula. In Artikel Asli 191 Sari Pediatri (Vol. 13, Issue 3).

[18] Rombot, G., Kandou, G. D., \& Ratag, G. A. E. (2014). Faktor-faktor yang berhubungan dengan pemberian susu formula pada bayi usia 0-6 bulan di wilayah kerja puskesmas Molompar Tombatu Timur Minahasa Tenggara. In Jurnal Kedokteran Komunitas dan Tropik (Vol. 2).

[19] Rukiah, A. N. B. dan A. B. Y., \& Yulianti, L. (2013). Asuhan Neonatus Bayi dan Anak Balita. CV Trans Info Media .

[20] Setiawan, D., \& Prasetyo, H. (2015). Metodologi penelitian kesehatan untuk mahasiswa kesehatan. Graha Ilmu.

[21] Soetjiningsih, \& Gde Ranuh, IG. N. (2013). Tumbuh Kembang Anak (2nd ed.). EGC.

[22] Sondakh, J. J. S. (2013). Asuhan Kebidanan Persalinan dan Bayi Baru Lahir. Erlangga.

[23] Sugiyono. (2013). Penelitian Kuantitatif Kualitatif dan R\&D. Alfabeta.

[24] Sunardi. (2008). Buku Ayah, Beri Aku ASI. PT Aqwam Media Profetika.

[25] Tehuteru, E. S., Hegar, B., \& Firmansyah, A. (2001). Pola Defekasi pada Anak Pola Defekasi pada Anak Pola Defekasi pada Anak Pola Defekasi pada Anak Pola Defekasi pada Anak. In 129 Sari Pediatri (Vol. 3, Issue 3).

[26] Walyani, E. S., \& Purwoastuti, Th. E. (2015). Asuhan Kebidanan Masa Nifas dan Menyusui. Pustaka Baru Press.

[27] WHO. (2016). Increasing Breastfeeding Could Save 800.000 Children and US\$ 300 Billion Every Year. The Lancet.

[28] Wiji, R. N. (2013). ASI dan Panduan Ibu Menyusui. Nuha Medika. 